\title{
TECHNICAL DEVELOPMENT
}

J. Sci. Soc. Thailand, 6 (1980) 90-100

\section{INVESTIGATION OF PHYSICAL STRENGTH OF THAI CERAMIC PRODUCTS}

DANIEL BREEN ${ }^{\mathrm{a}}$, WEERAPONG PAESUWAN, KIM SAKTUSNA, SOMCHAI TEPARAK, PORNTHEP TRIVIRIYANUPARA

Department of Physics, Faculty of Science, Chiang Mai University, Chiang Mai, Thailand

${ }^{a}$ Present address: Faculty of Engineering, King Mongkut Institute of Technology, Ladkrabang Bangkok.

(Received 15 January 1980)

\section{Summary}

Traditional ceramics are an important handicraft industry in northern Thailand. While of good artistic quality, the products have low physical strength. Design is limited by the necessity to achieve strength by thickness of ceramic material. The present work provides measurements of the modulus of rupture, which is a parameter of the physical strength. The shortcomings of the traditional products are readily seen by contrast with a product of the newly established Ceramics Branch of the Industrial Services Institute, Chiang Mai. The same materials have been studied at microscopic level where structural faults that influence physical strength are identified. The results of measurements of electrical properties are also included. It is suggested that measurement of the modulus of rupture is a convenient method of quality control in the handicraft industry.

\section{Introduction}

As a basis for quality control and to provide an insight into production problems, a physical investigation of certain properties of local ceramics has been initiated. An easily measurable and relevent parameter is the physical strength. Breakage of rectangular shaped samples under a slowly increasing stress gives the modulus of rupture, providing a convenient criterion of strength. However, macroproperties such as strength depend on internal structure, and the materials have been 
studied at microscopic level where the phase structure can be obsered. Measurements of phase distribution and porosity have been made. While not directly related to any present application, electrical properties also depend on material structure and constitution. Dielectric constant and loss factor have been measured. Finally, the densities of samples have been recorded.

Local ceramic industries use a clay from Mae Rim, Chiang Mai, usually referred to as Mae Rim ball clay. In general no adaptation is made of the naturally occurring clays other than washing, grinding and sieving to remove sand. For comparison with samples supplied by local industries, samples of products by the Ceramics Branch of the Industrial Services Institute (ISI), Chiang Mai, have been included in measurements. In the Institute refined techniques of clay preparation and firing are used to familiarize local workers with improved processing methods. The ceramic body used is made by mixing $65 \%$ kaolin (Lampang) and $15 \%$ Pyrophyllite (Chiang Rai) with only $20 \%$ of Mae Rim clay.

\section{Ceramic strength}

The body of pottery is a complex mixture of crystalline phases embedded in a glass-like matrix. Covalent bonding of a directional nature is prevalent so that the material fails in a brittle manner with little or no plastic deformation. The theory of brittle fracture relies on the presence and propagation of cracks in the material. The actual stress present at the tip of a small crack is several orders of magnitude larger than the average stress present in the body, leading to crack propagation and failure. The occurrence and propagation of cracks can be associated with the presence of pores, surface damage, abnormal grains or foreign inclusions. In the ceramics considered here the presence of pores and quartz grains are the most likely contributors to failure. In particular, crystalline quartz undergoes a phase transformation at $573^{\circ} \mathrm{C}$ which is accompanied by a volume increase of $0.86 \%$. For large grains the resulting stresses around the quartz can cause cracks through the grain or around its perimeter (Fig. 1). On the other hand, a small grain size of body material can limit the size of initial flaws, as well as retarding the propagation of a crack ${ }^{1}$. It is also expected that internal stresses produced by heat treatment during fabrication will be smaller in a fine grained material ${ }^{1}$.

The combined effect of pores and grian size on strength has been described by the empirical relationship:

$$
\mathrm{S}=\mathrm{kG}^{-\mathrm{a}} \exp (-\mathrm{bP})
$$

where $S$ is strength, $G$ is grain size, $P$ is the volume fraction of isolated pores, while $\mathrm{a}, \mathrm{b}$ and $\mathrm{k}$ are constants ${ }^{2}$.

\section{Microstructure}

In the present study microstructure refers to the details of phase and particle structure visible in the ceramic material under a low power microscope. Observa- 
tion is made both by reflected light from a ploished surface, and by transmitted light through a thin section. In the type of ceramic studied three principle phases can be identified, corresponding to different reflectivities under illumination (Fig. 2). There are dark and light phases as well as embedded quartz crystal grains. No identification has been made of the light and dark phases, but they probably correspond to the presence of clay particles (dark) in a glassy (light) feldspar matrix. Pores and quartz grains may be identified by their behaviour under polarized light in a thin section (Fig. 3). A further prominent feature is the presence of large empty faults which can easily be seen in the polished surfaces.

\section{Dielectric Constant}

The dielectric properties of a material are expressed by the complex permittivity $\varepsilon-\mathrm{j} \varepsilon^{\prime}$. The dielectric constant, $\varepsilon$, and the loss tangent, $\tan \delta=\varepsilon / \varepsilon^{\prime}$, are the quantities usually quoted for a material.

If the admittance of a real capacitor is equated to a capacitance $C_{x}$ in parallel with a resistance $R_{x}$, then

$$
Y=\frac{1}{R_{x}}+j \omega C_{x}
$$

where $\omega$ is the frequency of measurement. When the admittance $Y$ is measured before and after the introduction of a dielectric, the observed change in $\mathrm{Y}$ can be expressed as

$$
\Delta Y=\Delta\left(\frac{1}{R_{X}}\right)+j \omega \Delta C_{X}
$$

If $\mathrm{C}_{\mathrm{o}}=\pi \mathrm{r}^{2} / \mathrm{t}$, where $\mathrm{r}$ and $\mathrm{t}$ are the radius and thickness of the dielectric sample while $\varepsilon_{0}$ is the dielectric constant of air, then $\varepsilon^{\prime}$ and $\varepsilon$ are given by:

$$
\begin{aligned}
& \varepsilon^{\prime}=\frac{\Delta\left(1 / \mathrm{R}_{\mathrm{X}}\right)}{\omega \varepsilon_{\mathrm{o}} \mathrm{C}_{\mathrm{o}}} \\
& \varepsilon=1+\frac{\Delta \mathrm{C}_{\mathrm{x}}}{\varepsilon_{\mathrm{o}} \mathrm{C}_{\mathrm{o}}}
\end{aligned}
$$

Measurement of $\Delta\left(1 / R_{\mathrm{x}}\right)$ and $\Delta \mathrm{C}_{\mathrm{x}}$ allows the derivation of $\varepsilon$ and $\tan \delta$.

\section{Materials and Methods}

Samples of ceramic products were obtained from kilns in the Chiang Mai area. They are identified according to the method of production, whether by hand throwing, jiggering, or from a slip solution poured into a mould. Originally in the form of broken shards, samples were cut and polished as described in following sections.

a) Modulus of rupture is measured by applying a gradual stress to a bar of rectangular cross section until rupture occurs. Samples of various dimensions (lengths 5.0 to $8.0 \mathrm{~cm}$., widths 0.9 to $1.5 \mathrm{~cm}$., thicknesses 0.2 to $0.35 \mathrm{~cm}$.) are cut from the 
material. Surfaces were polished smooth to eliminate surface faults. The samples are supported at both ends as shown in Fig. 4. A circular shaped rod of wood across the centre of the sample supports a container which slowly fills with water. When rupture occurs, flow is stopped and the weight of water gives the breaking force.

$$
\text { Modulus of rupture }=\frac{3 P L_{g}}{2 b d^{2}}
$$

where $\mathrm{P}$ is the breaking force in kilograme

$L$ is the specimen length between supports in meters, $b$ the width

$\mathrm{d}$ is thickness in meters and $\mathrm{g}$ is acceleration due to gravity. The resulting value of modulus is in $\mathrm{MNm}^{-1}$.

The broken ends were examined under a microscope to assess the path of the line of break. Some sketches were made showing observed pore distribution along the break (Fig. 5).

b) Microstructure: Samples were mounted by epoxy cement in a bakelite ring and carefully ground in several stages. Beginning with coarse and fine grinding wheels the samples were next ground with carborundum, $\mathrm{Al}_{2} \mathrm{O}_{3}$ and diamond pastes. Final stages used 1 micron diamond paste followed by buffing with 0.3 micron $\mathrm{Al}_{2} \mathrm{O}_{3}$. Thin sections were made by grinding down a slice fixed on a glass slide until it was translucent.

Microscopic examination was made using a $16 \mathrm{X}$ objective and $8 \mathrm{X}$ eyepiece. The proportion of dark phase material was determined by drawing a line across photographs of the polished surface under reflected light and measuring the percentage of dark phase cut by the line. This is equal to the volume percentage of dark phase present in the material. To examine effects of clay crystal alignment in manufacture samples were cut from each piece of ceramic to give polished faces parallel and perpendicular to the surface.

Porosity was measured by point analysis on the thin sections. One hundred regularly spaced points were examined and the number of points which fell within a hole counted. This figure is equal to the porosity percentage. The identity of each pore was checked by using crossed polarizers. In this way they could be distinguished from crystal particles which look similar to pores under transmitted light.

c) Dielectric Constant: Samples were cut in the shape of cylindrical discs of diamater about $2.5 \mathrm{~cm}$ and thickness 0.2 to $0.3 \mathrm{~cm}$, and placed between circular plates of a condenser of diamater $4.2 \mathrm{~cm}$, mounted on the moving and stationary arms of a micrometer. The condenser plates are conveniently cut from copper faced printed circuit sheet. Reactance and conductance values were again measured. Subtracting the two values $\Delta\left(1 / R_{x}\right)$ and $\Delta C_{x}$ are obtained, from which $\varepsilon$ and $\tan \delta$ are derived. To check the method a measurement was made on a sample of fused quartz. The value measured, $3.7 \pm 0.1$, compares favourably with a quoted value of 3.8. Measurements made on combined sample discs also showed consistent results. 
The long dimension of large faults on the surface of one sample were measured. Finally, density values derived from physical dimensions and weight are given. The results are presented in a single table for easy comparison. Modulus of rupture figures are averages for five samples with standard deviation. Dark phase percentages are averages for fifteen lines for each sample with a standard deviation.

\section{Results and Discussion}

The most striking result (Table 1) is the superior strength of the ISI samples, measured by the modulus of rupture, confirming the advantages of the materials and procedures used in this Institute. An examination of the other numerical parameters presented does not lead to any correlation that would identify the structural causes of the increased strength. However examination of the photographs made of polished and thin sections gives certain clear indications. Photographs of the polished sections show that the body of the ceramic material is composed of a light continuous background forming a matrix for dark phase patches and quartz grains. Tentatively, we may identify the dark patches as accumulations of clay particles set in a glasslike body of feldspar origin. (As evidence compare the overall average of dark phase material, $41 \%$, and the estimated clay content of Mae Rim ball clay $39 \%$ ). The ISI sample shows an evenly distributed texture so that there are few, if any, large areas of light or dark phase. The contrast with other samples, especially $E$ the weakest of all, is striking. Strength deponds on grain size according to equation 1. A numerjcal comparison using this formula is not satisfactory as the wide variation in grain sizes, seen for example in Sample E, Fig. 2b, does not yield a meaningful average parameter. However the effect of the presence of the large grains due to the uneven distribution of the phases can be appreciated in a qualitative way.

TABLE 1. SOME PROPERTIES OF THAI GERAMIC PRODUCTS

\begin{tabular}{|c|c|c|c|c|c|c|c|c|}
\hline $\begin{array}{l}\text { Modult } \\
\text { Sample }\end{array}$ & $\begin{array}{l}\text { us of Rupture } \\
\text { e } \mathrm{MNm}^{-1}\end{array}$ & $\begin{array}{l}\text { Microstructure } \\
/ / \text { cut }\end{array}$ & $\begin{array}{l}\text { Dark Phase } \\
1 \text { cut }\end{array}$ & $\%$ & $\begin{array}{l}\text { Porosity } \\
\text { Size } \times 105 \mathrm{~m}\end{array}$ & $\begin{array}{l}\text { Dielectri } \\
\boldsymbol{\varepsilon}\end{array}$ & $\begin{array}{c}\text { c Constant } \\
\tan \delta\end{array}$ & $\begin{array}{c}\text { Density } \\
\mathrm{Kg} / \mathrm{m}^{3} \times 10^{-3}\end{array}$ \\
\hline A & $77.1 \pm 1.5$ & $42 \pm 8$ & $43 \pm 13$ & 8 & 3.4 & $10.10 \pm .04$ & $0.368 \pm .007$ & 2.21 \\
\hline B & $48.8 \pm 0.8$ & - & - & - & - & $6.16 \pm .02$ & $0.104 \pm .002$ & - \\
\hline C & $40.0 \pm 0.6$ & $53 \pm 14$ & $47 \pm 9$ & 5.5 & 1.9 & $5.20 \pm .02$ & $0.138 \pm .003$ & 2.20 \\
\hline D & $35.5 \pm 1.0$ & $38 \pm 11$ & $36 \pm 5$ & 12 & 5.3 & $5.04 \pm .02$ & $0.095 \pm .002$ & 2.06 \\
\hline $\mathrm{E}$ & $31.6 \pm 1.0$ & $32 \pm 6$ & $37 \pm 8$ & 18 & 7.5 & $5.36 \pm .02$ & $0.176 \pm .004$ & 2.15 \\
\hline $\mathrm{F}$ & $12.6 \pm 0.4$ & - & - & - & - & $=$ & - & 1.70 \\
\hline
\end{tabular}

Key: A; ISI Slip B:ISI hand thrown C; Thai Celadon slip D; Thai Celadon jigger $\mathrm{E}$; Mengrai Kiln hand thrown F; Thai Celadon biscuit fired

Long dimension of large faults in sample $\mathrm{D}$ measured on surface of polished sample in order of size $\begin{array}{lllll}\text { 1. } 0.79 & \text { 2. } 0.39 & 3.0 .29 & \text { 4. } 0.28 \mathrm{~mm}\end{array}$

An examination of the quartz grain distribution in the same samples leads to a similar conclusion. Although the ISI sample was observed to contain quite 


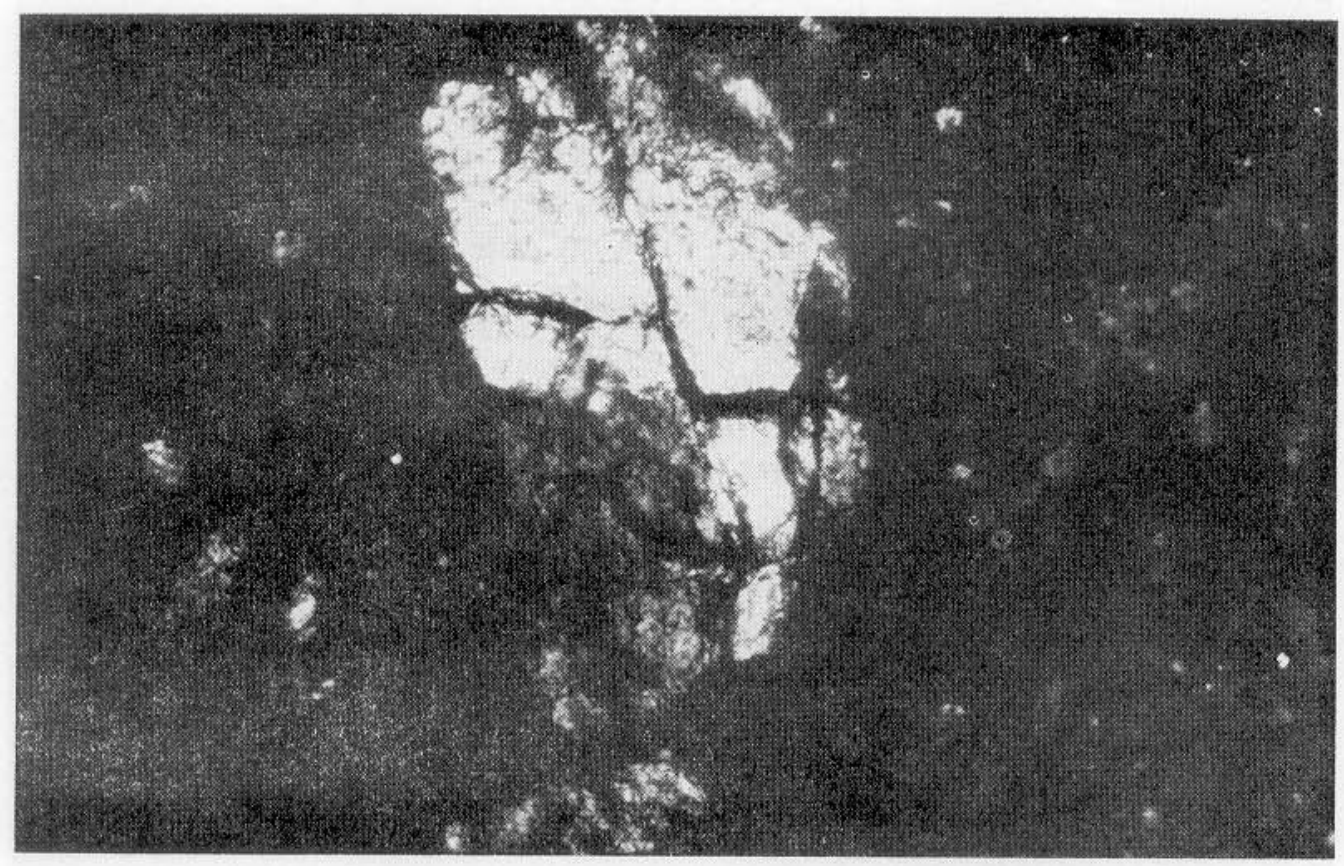

Fig. 1. Quartz grain in body of ceramic, 180X. 


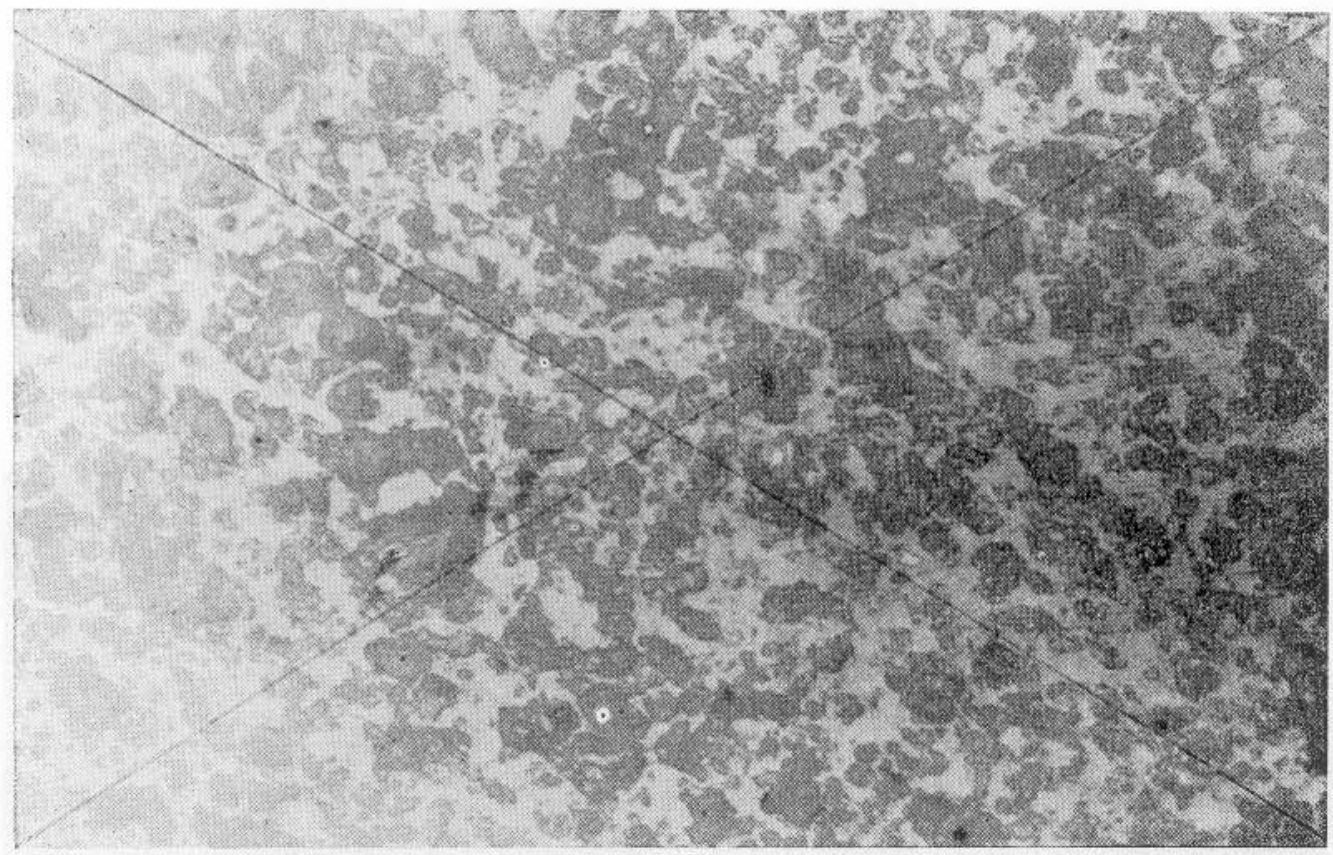

Fig. 2A. Polished face of ceramic, ISI slip sample; 180X. Diagonal lines in this and the following photograph are drawn for phase measurement as described in the text.

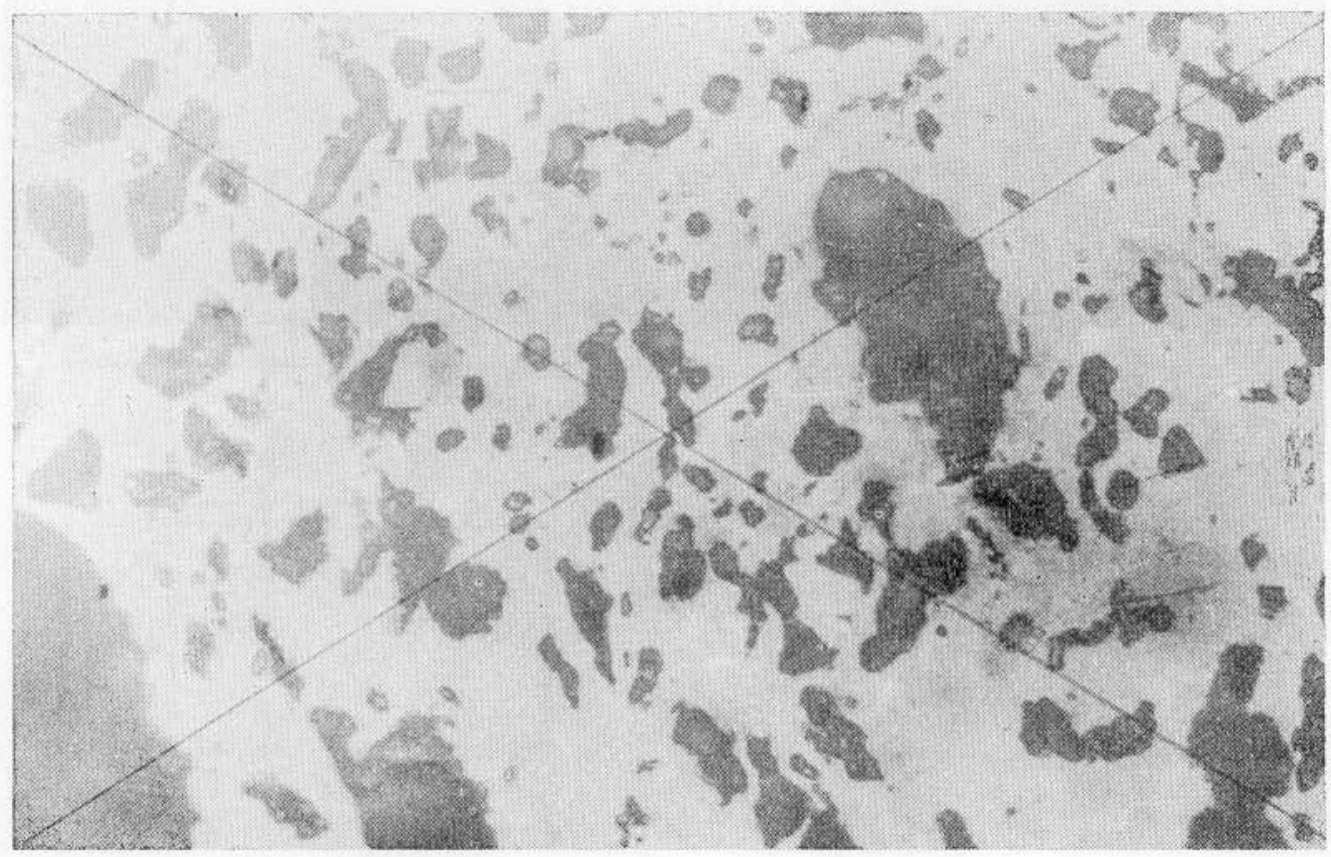

Fig. 2B. Polished face of crystal, Mengrai Kiln hand thrown semple; $180 \mathrm{X}$. 

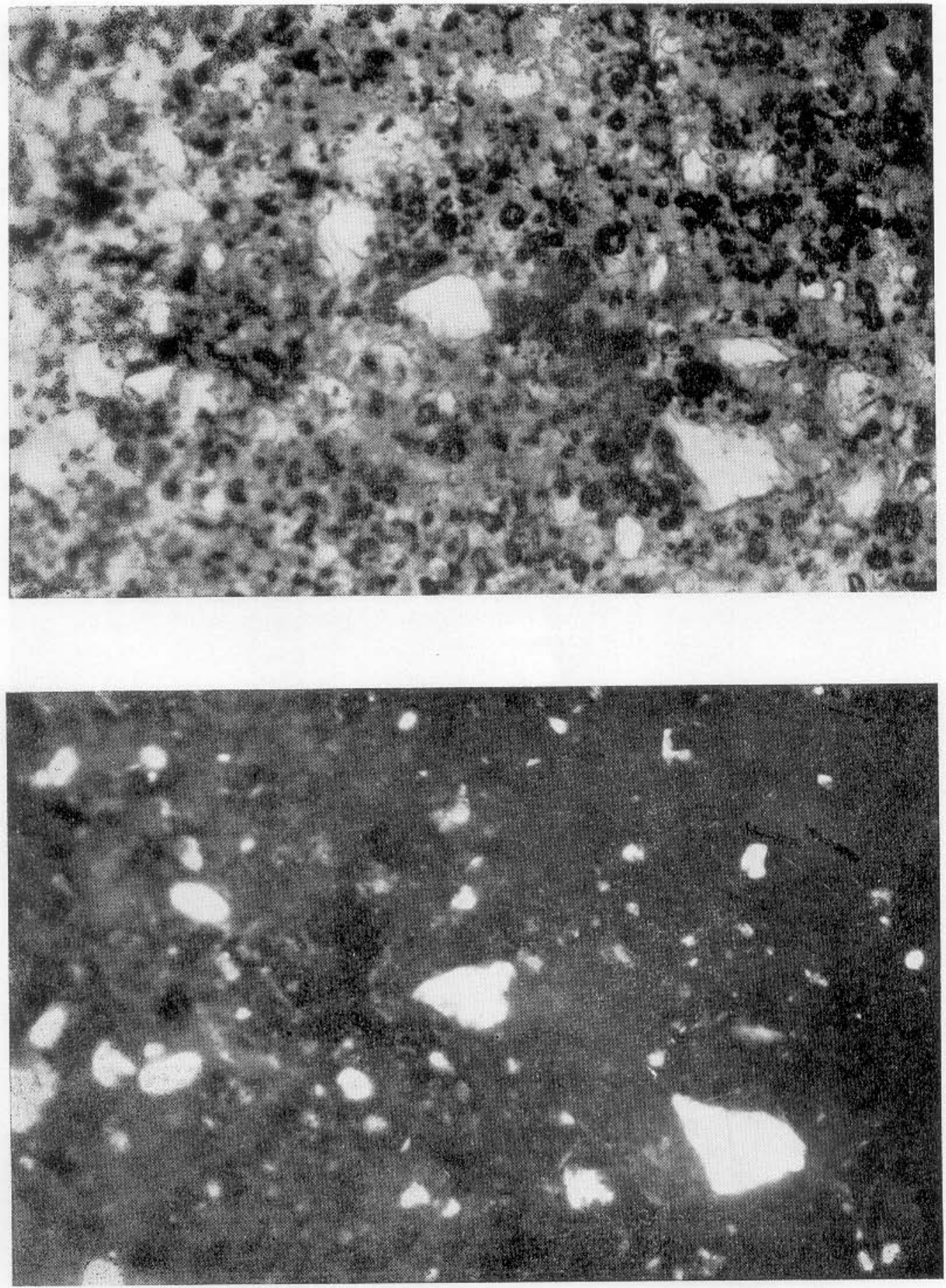

Fig. 3. Thin section, direct light (upper) and crossed polarizers (lower); 180X. 


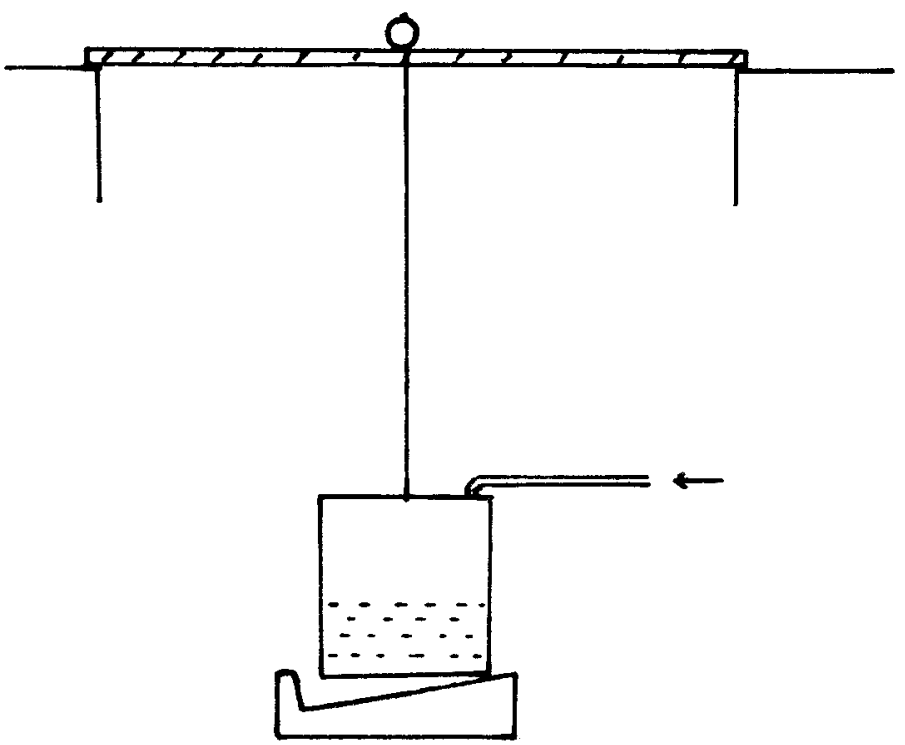

Fig. 4. Modulus of rupture measurement. Sample under increasing load as water container fills.
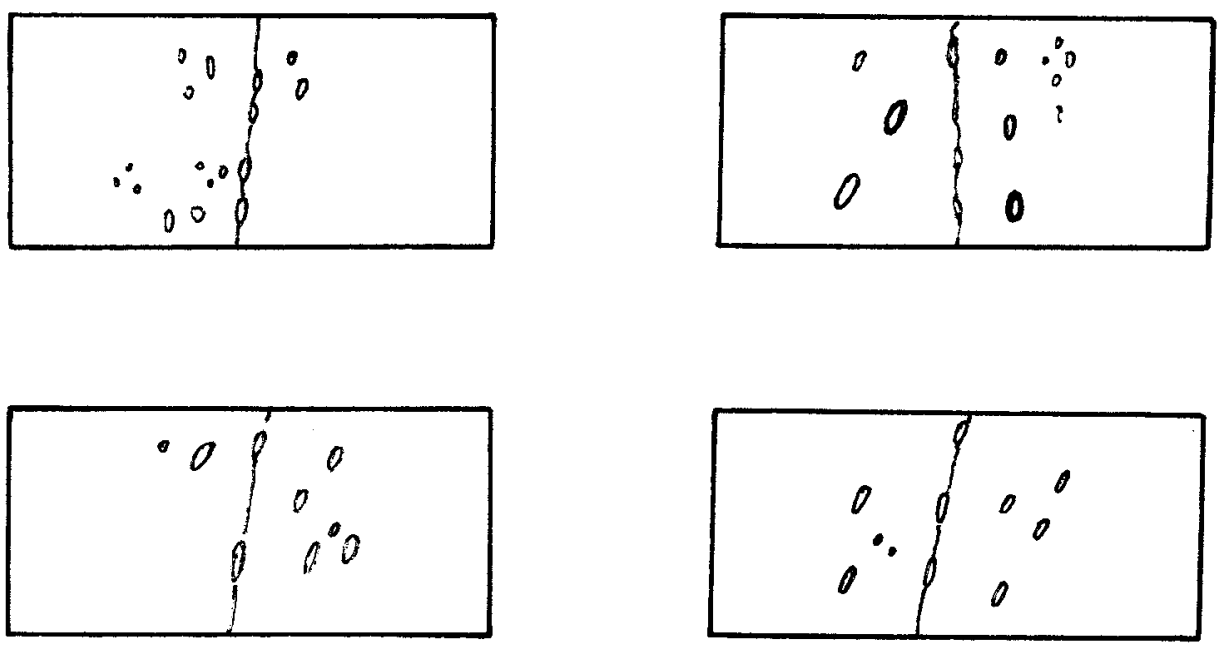

Fig. 5. Pore distribution along line of fracture. 
large fractured grains (Fig. 1), these isolated units appear to have less effect than the overall distribution in the body of the ceramic.

The presence of large faults, for which sample dimensions are given, is also likely to contribute to weakness. These faults were noted to be less in slip samples and indicate a likely cause for the fact that the slip samples $A$ and $C$ are stronger than the corresponding handthrown or jigger samples $B$ and $D$, although the samples pairs from the same source, such as $C$ and $D$, are made from the same raw materials and undergo the same firing process. There faults are usually long and thin. They probably occur in the packing and kneading of the lump of clay so that they would be less likely to appear in the slip made samples. However such faults were noted to a similar degree in all samples processed in the same way.

Sketches of the pore distribution on a fracture face suggest the role played by such vacancies in facilitating a fracture line. But this cannot be the most important factor involved, as is shown by the higher porosity but also greater strength of sample A compared with sample $C$.

Summarizing the results of inspection of the microscopic surface pictures, we can suggest that the superior strength of the ISI samples derives from a ceramic body having a more evenly distributed component structure. This could be due to three factors:

a) a better relative mixture of raw materials

b) better processing, i.e. grinding, sifting etc.

c) better firing and cooling, leading to a more evenly distributed and smaller crystallite structure in the body.

While ISI certainly aims at improvement in aspects b) and c), the basic mix was adopted with the express intention of bettering the quality of the ceramic products, so this may indeed be the most important factor. The average clay content of porcelain body from several producing countries ${ }^{3}$ is $52 \pm 9 \%$, while the Mae Rim deposit, 39\% clay, is significantly lower. The addition of kaolin by ISI raises the clay content of the body mix.

However the appearance of the phase distribution shown in Fig. 2 suggests that mixing and cooling also play a part. Further work remains to be done in clarifying the causes of the ISI improved ceramic body. Meanwhile, it is suggested that the expremely simple modulus of rupture measurement method is useful as a means of quality control within the handicraft industry. The method already indicates in a striking way the gap in quality between traditional products and those where some improving techniques are applied.

\section{References}

1. Kingery, W.D., Bowen, H.K. and Uhlmann, D.R. (1976) Introduction to Ceramics, Wiley. New York.

2. Hove, J.E. and Riley, W.C. (1965) Modern Ceramics, Wiley, New York.

3. Kato, Y. (1976) The Preparation of Body and Glaze, Industrial Services Institute, Chiang Mai. 


\section{บทคัคย่อ}

เครื่องบั้นดินเผาแบบที่ทำกันมาแต่เดิมนน้น เบ็นงานผืมือที่มีคุณค่าทางศิลป และเบ็นอุตสาหกรรมที่มี ความสำคัญมากในภาคเหนือของประเทศไทย แต่มีข้อเสียคือไม่ค่อยแข็งแรง การออกแบบจึงต้องถูกจำกัดลง

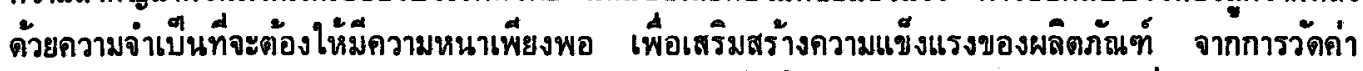
ความแข็งแรง (modulus of rupture) ได้แสดงให้เห็นถึงข้อบกพร่องของผลิตภัณฑ์ที่ทำกันมาแต่เดิม เมื่อนำมาเปรียบเทียบกับผลิตภัณฑ์ของแผนกเครื่องบี้นดินเผา กองบริการอุตาหกรรม ซึ่งพึ่งตั้งข้นมาที่เชียง ใหม่ แสดงให้ห็นว่าการวัดค่าความแข็งแรง (modulus of rupture) จะเบ็นวิธีที่เหมาะสมสำหรับการ ควบคุมคุณภาพของอุตสาหกรรมประเภทน ได้รวมผลจากการวัดคุณสมบติทางไฟพ้าไว้ด้วย จากการศึกษาใน ส่วนย่อยของวัสดุที่นามาใช้ จะสามารถเห็นถึงข้อผิดพลาดของโครงสร้างที่มีผลต่อความแข์งแรงของเครื่องบี้น ตินเผาได้ 